scientist's reputation by overheated statements in the classroom or in published articles.

In the court fight between Hoffman LaRoche and the University of California at Los Angeles (UCLA) over how Hoffman LaRoche obtained a KG1 cell line belonging to the university, the company also named individually two UCLA scientists, David W. Golde and H. Philip Koeffler. It also named Golde separately and accused him of slandering the company. The university is conducting the entire case, including the parts in which the individuals are named, and carrying the costs.

Golde's view is that he therefore does not need the insurance policy now being offered. (Moreover, the university has a malpractice policy that covers him because he is also a physician.) But he warns that "there is not always a 100 per cent congruence of interests between a faculty member and his university in this kind of situation".

As for the likelihood that a university, after defending one of its faculty, would turn round and sue him, Harvard's general counsel Daniel Steiner says it is "farfetched".

The brochure does not mention the problem of liability for new organisms created through gene-splicing: would the policy cover, for example, a scientist who invents a bug that eats Manhattan, as one observer phrased it? But the policy would in any case be of only marginal use in that situation. For one thing, the likely damages would exceed the \$1 million liability limit. Moreover it does not cover any "punitive", damages - the extra penalties a judge can impose to deter the scientist from, say, turning his bug loose on Chicago.

Deborah Shapley

\section{Soviet technology}

\section{Red tape blamed for delay}

Soviet bureaucrats - not scientists should be blamed for persistent delays in the introduction of new technology, Academician Anatolii P. Aleksandrov, president of the Soviet Academy of Sciences, said last week. He was commenting on the recent plenum of the Central Committee of the Communist Party of the Soviet Union, which, in his words, had put "new pressure" on the drive for the more rapid implementation of new technology. This drive was a major issue in the policy of the late President Leonid Brezhnev, and the stress that the plenum put on it seems an intensification rather than a change in policy. Dr Aleksandrov, however, may find his own position under the new administration more vulnerable. It is widely believed that, although he was elected by the academy in a secret ballot in the regular way, his candidacy was known to enjoy the support of $\mathrm{Mr}$ Brezhnev, and there has been considerable speculation that with $\mathrm{Mr}$ Brezhnev gone, Dr Aleksandrov may now be replaced as president of the academy.

In any case, as president of the academy, Dr Aleksandrov holds considerable responsibility for the technological modernization programme, since, during the last five-year plan, the academy was given a major coordinating role and charged with establishing and strengthening links between researchers and industrial customers. This move followed a wave of criticism of scientists for not pulling their weight with those science centres which had been specially created to serve the needs of local industry singled out for special blame - starting with the relatively small Far Eastern Science Centre, and working up to the prestigious Siberian branch of the Academy of Sciences. The scientists retaliated vocally, blaming the administrators and managers who failed to implement their recommendations.

Scientists were again blamed earlier this autumn. On 20 October, Pravda carried an article by two senior officials alleging that research potential was being wasted and misapplied in the various institutes of the Academy of Agricultural Sciences. Three days later, in an interview on Moscow radio, Dr Vladimir Shumnyy, deputy director of the Cytology and Genetics Institute of the Siberian branch of the Academy of Sciences, tacitly denied the accusation, citing an impressive list of joint achievements of the Siberian branches of the two academies, from the development of the hardy Novosibirskaya-607 winter wheat and a strain of sheep with a 50 per cent increased wool yield to the hormonal control of plant growth and pig fertility and the protection of grain by irradiation.

Such a media dialogue is a well-known ploy in Soviet journalism; a new drive is launched and backsliders rebuked, and then a selected representative of those under attack states his case. The matter may then be dropped (on the assumption that those who deserved criticism will have profited by the warning), or else may go on to become a full-scale press campaign of criticism, culuminating in a new party and government decree.

What was not routine in this case was, of course, the death of Mr Brezhnev, which necessitated the convening of the Central Committee plenum, and the latter's announcements of, effectively, new party directives. For Dr Aleksandrov, who, only a few days before, had on behalf of Soviet science, made one of the five valedictory speeches at Brezhnev's funeral, it was time to make his position clear. The scientists had produced the designs, he said, and in some cases they were implemented "quite rapidly and effectively"'. In many ministries, however, the need for updating technology had been discussed for years, but scientists had not yet been able to establish "proper working contacts". The result was waste, inefficiency and delays. The firm reiteration of the problem by the plenum, he hoped, would get things moving again. He stressed, however, that if the scientists' work is not to be wasted, economic managers should be more accountable for their work in implementing new technology.

Vera Rich

\title{
EEC dependence on Soviet national gas
}

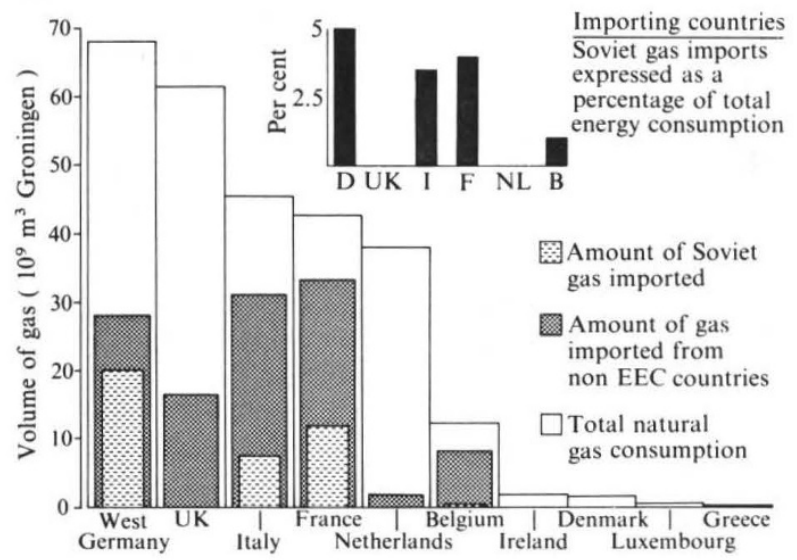

The figure shows the dependence of the European Economic Community (EEC) on imports of natural gas with particular reference to the Soviet Union. Natural gas now accounts for 18 per cent of the total energy consumption of the EEC, compared with just 7 per cent in 1970. But fears that demands for imported gas may lead to an increased dependence on Soviet supplies appear to be unfounded, as shown by the situation envisaged for 1990 which is illustrated here. Gas imported from non-EEC countries will account for $\mathbf{4 4}$ per cent of the total amount of gas required. Of this, 19 per cent will come from the Soviet Union, accounting for only 4 per cent of the total energy consumption. Other non-EEC suppliers will be Norway (12 per cent of natural gas imports), Algeria (10 per cent) and Libya ( 1 per cent), and 2 per cent will come from unspecified sources. 